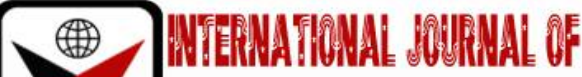

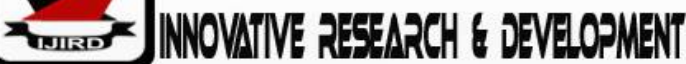

ISSN 2278-0211 (Online)

\section{Relative Effectiveness of Demonstration and Project-Based Teaching Methods in Developing Male and Female Psychomotor Skill and Interest in Electrical Installation and Maintenance Work}

J. I. Ezenwafor
Professor, Department of Technology and Vocational Education,
Nnamdi Azikiwe University, Awka Anambra State, Nigeria
K. R. E. Okoye
Professor, Department of Technology and Vocational Education,
Nnamdi Azikiwe University, Awka Anambra State, Nigeria
C. O. C. Obi
Lecturer, Department of Electrical/Electronic Technology Education,
Federal College of Education (Technical), Umunze Anambra State, Nigeria

\section{Abstract:}

The study was necessitated by the need to improve psychomotor skills acquisition and interest of both male and female students in electrical installation and maintenance work in technical colleges. It ascertained the relative effectiveness of demonstration and project-based teaching methods in developing male and female students' psychomotor skills and interest in electrical installation and maintenance work in technical colleges in Anambra State. Four research questions and four null hypotheses guided the study. Quasi-experimental design, specifically, the pre-test, post-test non-equivalent research design was adopted for the study. Population comprised 343 National Technical Certificate 11 (NTC) students in all the twelve technical colleges in the state. Purposive sampling technique was used to draw a sample size of 80 students from two colleges based on schools that have good number of male and female students. Psychomotor Skill Performance Test in Electrical Installation and Maintenance Work (PSPTEIMW) and Interest Inventory Scale on Electrical Installation and Maintenance (IISEIMW) were used to collect data for the study. The PSPTEIMW has been validated by test developers in the National Business and Technical Examination Board while IISEIMW was face validated by three experts in the fields of technical education and educational measurement and evaluation. A pilot study was used to establish the reliability of the instruments by administering them to 30 NTC II students of government technical college Okporo, Orlu in Imo state who were not part of the population of the study. Internal consistency of the instruments was determined using Cronbach Alpha technique and reliability coefficient values of 0.82 and 0.80 were obtained respectively. Data collected were analyzed using arithmetic mean to answer the research questions and analysis of covariance (ANCOVA) to test the hypotheses at 0.05 level of significance. The findings revealed that the project-based method improved male and female students' psychomotor skill development while both methods equally promoted male and female students' interest in electrical installation and maintenance work. There was significant difference in the psychomotor skills development of male and female students in favour of the project-based method but no significant difference in the interest scores of the students. Based on the findings, it was concluded that adoption of demonstration and project-based teaching methods by technical teachers will lead to an improvement in psychomotor skill development and interest in the trade among male and female students of technical colleges. It was, therefore, recommended among others that technical teachers should adopt the methods consistently to develop students' psychomotor skills and interest in trades in technical colleges in Nigeria.

Keywords: Electrical installation and maintenance work, psychomotor skill, interest, demonstration and project-based teaching method, gender

\section{Introduction}

Electrical installation and maintenance work is a trade in electrical/electronic option in technical colleges which provides learners with knowledge and practical skills required to become effective and efficient technicians in the field. Such persons are needed for employment in organizations like Electricity Distribution Company (EDC), manufacturing, mining, oil and gas industries. According to the National Business and Technical Education Board (2010), electrical installation and maintenance work comprises three modules, namely; domestic and industrial installation, cable jointing and battery charging and winding of 
electrical machine. Additionally, graduates of this programme are expected to develop psychomotor skills in installing, operating, maintaining and repairing of electrically energized systems such as residential, commercial and industrial building as well as equipment. There is need for effective teaching in electrical installation and maintenance work because anything less would not only cause threat to the lives and properties of electricity users but will also worsen unemployment and poverty among the products (Ogbuanya and Akinduro, 2017). Ogbuanya, et al affirmed that students can only be proficient in handling different tasks in installation and maintenance when teachers employ appropriate teaching methods to enable them effectively acquire knowledge and develop the psychomotor skills. Psychomotor skills are those capabilities involved in a task or various tasks that learners are expected to acquire as a result of persistent practice (Ayonmike, 2014). They are those skills or special abilities required by a learner in human activities which can be acquired through learning and constant practice. Additionally, Ayonmike stated that principles that guide psychomotor skill development are necessary in the education process for it to contribute to the development of a nation through effective human capital development that meet employment requirements.

Regarding the need for adoption of appropriate teaching methods in technical colleges, Okoye (2016) asserted that since technical education programme is skill-based, teaches should widely adopt teaching methods that facilitate psychomotor skills development in order to equip learners with the capability and capacity to design, produce and use technological products and systems as well as assess the appropriateness of technological action. Consequently, Okoye emphasized that there should be adjustment in the programme of technical colleges. In the same vein, Eze and Osuyi (2018) asserted that adjustment in technical education programme will affect the curricular implementation processes which are prosecuted through different learning experiences and contents. This is in line with the recommendation of the Federal Republic of Nigeria (FRN, 2014) that modern educational instructional methods should be increasingly used and improved upon at all levels of the education system.

The major implication of the recommendation of FRN (2014) is that educators must be in constant search of teaching methods and techniques that could improve their practice, encourage learners to participate actively in the teaching and learning process and adapt more perfectly to classroom situations geared towards meeting the needs of students and by extension those of the industry and society at large. Several teaching methods have been documented as being effective in teaching psychomotor skills, improving students' performance and interest in technical education programmes generally and especially in electrical installation and maintenance work. These methods include discussion, demonstration, guided discovery, project-based, problemsolving methods and field trips among others. Many instructors are aware of these instructional methods and techniques but most technical teachers simply opt to utilize the conventional (chalk-talk) method despite the unique benefits of the others as highlighted below.

Demonstration method of teaching allows students to make use of all their senses- sight, smell, taste, hearing and touch (Omeje and Onaga, 2015). Edu, Ayang and Idaka (2012) explained that students learn physical or mental skills by actually performing them under supervision,. Furthermore, Daluba (2013) affirmed that teacher-student demonstration method is generally effective in teaching practical subjects in science, technical and vocational education. However, Edu, et al observed that in using demonstration teaching method, giving students assignments/projects is inevitable to enable them better acquire the needed skills. Such measures enhance the teaching-learning process.

Project-based method of teaching is one of the instructional methods recommended for use by technical instructors as it enables students to participate actively in the teaching and learning process. According to Omeje and Onaga (2015), projectbased teaching method involves units of activities carried out by students in a spirit of purpose to accomplish a defined, attractive and predetermined goals based on their background knowledge and experience. The authors further explained that project-based teaching method is like assignment method in which a task is given to students or a number of tasks are shared to students to carry out allowing a great deal of student involvement right from the planning stage, the sketching of the project, the steps of executing it, the tools, equipment and materials to be used in the project. This enables students to conceptualize the content and put the task into practice repeatedly in order to improve their psychomotor skills development and interest in the field for societal development.

The goal of effective teaching and learning is to enhance academic achievement and skill acquisition. Okoro (2013) explained that achievement is qualified by the measure of the students' academic standing in relation to those of other students of the same age. In the school setting, academic achievement connotes performance (psychomotor skill development inclusive) in a subject or many subjects as symbolized by the score or mark obtained by students in a test or examination (Eze, Ezenwafor, Obidile, 2016). According to Eze (2006) psychomotor skill development of students includes their acquired and retained physical and mental skills through the course of study within and outside the classroom situations. Psychomotor development skills of students are quantified by a measure of the proficiency in demonstrating the skill in comparison with other students of the same age.

Students' interest in a subject could determine their academic and psychomotor skills achievement (Okigbo \& Okeke, 2011).According to Okigbo, et al, interest is an emotionally-oriented behavioral change which determines students' vims and vigor in tackling educational tasks or other activities. The authors emphasized that the choice of instructional method may impact positively or negatively on the quality of knowledge accumulation of learners irrespective of their interest in the subject. More so, students' interest and achievement in any learning activity is sustained by their active involvement in the teachinglearning process. Stressing on the need for teachers to stimulate and sustain students' interest in the teaching and learning process, Okigbo and Okeke affirmed that students' achievement will be minimal if they lack interest in either the subject or the teacher.

According to Okigbo, et al (2011), it is very essential that the methods used by teachers in teaching skill courses should stimulate and sustain the interest of all students irrespective of gender.Agbejoye and Adegbola (2017) affirmed that gender could have influence on students' achievement and interest in different fields of study. The authors further asserted that professions like engineering, arts and crafts are generally regarded as men's field while others like catering, typing and nursing are regarded as women's. Generally, tasks that are regarded as complex and difficult are allocated to boys whereas girls are expected to handle the relatively easy and less demanding tasks. As a result of this way of thinking, the society tends to regard females as the weaker "Sex" and the average Nigeria girl goes to school with these fixed stereotypes.Therefore, there is need to investigate the relative 
effectiveness of demonstration and project-based teaching methods in developing male and female students'psychomotor skills and interest in electrical installation and maintenance work in technical colleges in Anambra State.

\subsection{Statement of the Problem}

Conflicting reports on the effect of teaching methods on students' psychomotor skills development and interest across gender in some technical subjects have shown that gender differences in psychomotor skill development and interest is not as a result of inherent biological differences but due to gender-role stereotyping. The high level of unemployment in Nigeria and other countries of the world require that educational institutions should ensure that students acquire relevant knowledge and skills in their different fields of learning to be gainfully employed on graduation. Technical subjects are skill-based courses of study offered in technical colleges and some higher educational institutions. The options include electrical/electronics, automechanics and building/wood. A key trade subject in the electrical/electronics option is electrical installation and maintenance work. Psychomotor skill is the major distinguishing aspect of technical education which makes it outstanding from liberal arts. Electrical installation and maintenance work comprises three modules namely; domestic and industrial installation, cable jointing and battery charging and winding of electrical machine. Products of the programme are expected to develop psychomotor skills in installing, operating, maintaining and repairing of electrically energized systems such as residential, commercial and industrial buildings and equipment if technical teachers adopt suitable methods to making the teaching and learning process sufficiently effective.

The problem of this study is that a large number of the products of technical colleges in Nigeria and Anambra State including those that studied electrical/electronics continue to roam the streets in search of employment years after graduation because employers consider them as half-baked and unemployable due their lack of relevant skills for effective work performance. This could be as a result of technical teachers' use of unsuitable teaching methods that will sustain the interest of both male and female students in all the components of the option including electrical installation and maintenance work and enable them adequately develop psychomotor skills. Different methods have been documented as being effective in teaching technical education programmes especially electrical installation and maintenance work trade to enhance students' interest and adequately equip them with psychomotor skills. These methods include discussion, demonstration, guided discovery, projectbased methods, problem- solving and field trips among others. However, it is not clearly known which of these methods will enhance male and female students' psychomotor skills development and interest in electrical installation and maintenance work. This make the study on relative effectiveness of demonstration and project-based teaching methods in developing psychomotor skills and interest of male and female students in electrical installation and maintenance work in technical colleges to provide empirical data that will enable relevant stakeholders take objective remedial actions.

\subsection{Research Objectives}

- what is the average mean score of achievement for male students in electrical installation and maintenance work when they taught using demonstration teaching method compared to those taught using project-based teaching method?.

- What is the interest mean score for male students in electrical installation and maintenance work when they taught using demonstration teaching method compared to those taught using project-based teaching method?.

- What is the average mean score of achievement for female students in electrical installation and maintenance work when they taught using demonstration teaching method compared to those taught using project-based teaching method?.

- What is the interest mean score for female students in electrical installation and maintenance work when they are taught using demonstration teaching method compared to those taught using project-based teaching method?.

\subsection{Null Hypotheses}

- Academic achievement mean scores of psychomotor skills of male students taught electrical installation and maintenance work using demonstration teaching method have no significant difference compared to those being taught using project-based teaching method.

- $\quad$ Interest mean scores of male students taught electrical installation and maintenance work using demonstration teaching method have no significant difference compared to those being taught using project-based teaching method.

- Academic achievement mean scores of psychomotor skills of female students taught electrical installation and maintenance work using demonstration teaching method have no significant difference compared to those being taught using project-based teaching method.

- Interest mean scores of female students taught electrical installation and maintenance work using demonstration teaching method have no significant difference compared to those being taught using project-based teaching method.

\section{Method}

Quasi experimental design was adopted for the study, specifically pre-test, post-test, non-equivalent control with no randomization. This design was adopted because it is not possible for the researchers to randomly sample the subjects and assign them to groups without disrupting the academic progrmme and time table of the schools involved in the study. The study was carried out in Anambra State which is one of the five states in the South-East Nigeria. Population of the study was 343 (235 males and 108 females)National Technical Certificate11 (NTC11) electrical installation and maintenance work students in all the 12 technical colleges in the statein the 2018/2019 session. Purposive sampling technique was used to draw two intact classes of 80 (50 males and 30 females) students from two colleges for the study based on the number of male and female students and availability of facilities for practical activities. Toss of a coin was used to assign one intact class to experimental group 1 (demonstration teaching method) and the other to experimental group 2 (project-based teaching method). 
Instruments for data collection were Psychomotor Skill Performance Test in Electrical Installation and Maintenance Work (PSPTEIMW) and Interest Inventory Scale in Electrical Installation and Maintenance Work (IISEIMW). The instruments were validated by three experts (two from Technology and Vocational Education Department and one from Measurement and Evaluation Unit of Educational Foundation Department), all in Nnamdi Azikiwe University Awka. A pilot study was used to establish the reliability of the instruments by administering them to 30 NTC II students of Government Technical College Okporo, Orlu in Imo state who were not part of the population of the study. Internal consistency of the instruments was determined using Cronbach Alpha technique and reliability coefficient values of 0.82 and 0.80 were obtained respectively. Arithmetic mean and standard deviation were used to analyze data relating to the research questions while Analysis of Covariance (ANCOVA) was used to test the null hypotheses at 0.05 level of significance

\section{Results}

\subsection{For Research Objective1}

\begin{tabular}{|c|c|c|c|c|c|c|}
\hline Teaching Method & & \multicolumn{2}{|c|}{ Pre-test } & \multicolumn{2}{c|}{ Post-test } & Mean Gain \\
\hline & N & Mean & SD & Mean & SD & \\
\hline Demonstration TM & 28 & 6.60 & 2.72 & 12.90 & 3.85 & 6.30 \\
\hline Project-based TM & 22 & 7.27 & 2.18 & 17.68 & 2.74 & 10.40 \\
\hline
\end{tabular}

Table 1: Mean and Standard Deviation of Academic Achievement Mean Scores of Psychomotor Skills of Male Students Taught Using Demonstration Teaching Method and Those Taught Using Project-Based Teaching Method

Table 1 indicates the mean scores obtained through pre-test and post-test for academic achievement of psychomotor skills of male students taught electrical installation and maintenance work using demonstration teaching method and those taught using project-based teaching method were 6.60 and 12.90 with mean gain of 6.30 . Those taught with project-based teaching method had 7.27 and 17.68 with mean gain of 10.40 . However, for each of the groups, the post-test means were greater than the pre-test means with the male in the project-based group having a higher mean gain. This shows that project-based teaching method has more relative effect on male students' psychomotor development skills in electrical installation and maintenance work than demonstration teaching method.

\subsection{For Research Objective 2}

\begin{tabular}{|c|c|c|c|c|c|c|}
\hline Teaching Method & & \multicolumn{2}{|c|}{ Pre-test } & \multicolumn{2}{c|}{ Post-test } & \multirow{2}{*}{ Mean Gain } \\
\hline & N & Mean & SD & Mean & SD & \\
\hline Demonstration TM & 28 & 2.55 & .90 & 3.66 & .37 & 1.10 \\
\hline Project-based TM & 22 & 2.64 & 1.11 & 3.76 & .39 & 1.11 \\
\hline
\end{tabular}

Table 2: Mean and Standard Deviation of Interest Mean Scores of Male Students Taught Using Demonstration Teaching Method and Those Taught Using Project-Based Teaching Method

Table 2 shows the pre-test and post-test interest mean scores of male students taught using demonstration teaching method and those taught using project-based teaching method were 2.55 and 3.66 with mean gain of 1.10 . Those taught with project-based teaching method had 2.64 and 3.76 with mean gain of 1.11 . However, for each of the groups, the post-test means were greater than the pre-test means. This shows that both teaching methods have relative effects on male students' interest in electrical installation and maintenance work.

\subsection{For Research Objective 3}

Analysis of data in respect of this research question is presented in Table 5

\begin{tabular}{|c|c|c|c|c|c|c|}
\hline & & \multicolumn{2}{|c|}{ Pre-test } & \multicolumn{2}{|c|}{ Post-test } & \multirow{2}{*}{ Mean Gain } \\
\hline Group & N & Mean & SD & Mean & \\
\hline Demonstration TM & 14 & 7.70 & 1.78 & 11.90 & 2.22 & 4.20 \\
\hline Project-based TM & 16 & 8.38 & 2.22 & 16.61 & 2.37 & 8.22 \\
\hline
\end{tabular}

Table 3: Mean and Standard Deviation of Academic Mean Achievement Scores of Psychomotor Skills of Female Students Taught Using Demonstration Teaching Method and Those Taught Using Project-Based Teaching Method

Table 3 shows the pre-test and post-test academic achievement mean scores of psychomotor development skill of female students taught electrical installation and maintenance work using demonstration teaching method and those taught using project-based teaching method were 7.70 and 11.90 with mean gain of 4.20 . Those taught with project-based teaching method had 8.38 and 16.61 with mean gain of 8.22 . However, for each of the groups, the post-test means were greater than the pre-test means with the female in the project-based teaching method group having a higher mean gain. This shows that projectbased teaching method has more effect on female students' psychomotor development skill in electrical installation and maintenance work than demonstration teaching method. 


\subsection{For Research Objective 4}

\begin{tabular}{|c|c|c|c|c|c|c|}
\hline & & \multicolumn{2}{|c|}{ Pre-test } & \multicolumn{2}{c|}{ Post-test } & \multirow{2}{*}{ Mean Gain } \\
\hline Group & N & Mean & SD & Mean & SD & \\
\hline Demonstration TM & 14 & 2.69 & .90 & 3.61 & .29 & 0.92 \\
\hline Project-based TM & 16 & 2.85 & .83 & 3.58 & .37 & 0.72 \\
\hline
\end{tabular}

Table 4: Mean and Standard Deviations of Interest Mean Scores of Female Students Taught Using

Demonstration Teaching Method And Those Taught Using Project-Based Teaching Method

Table 4 shows the pre-test and post-test interest mean scores of female students taught electrical installation and maintenance work using demonstration teaching method and those taught using project-based teaching method were 2.69 and 3.61 with mean gain of 0.92 . Those taught with project-based teaching method had 2.85 and 3.58 with mean gain of 0.72 . However, for each of the groups, the post-test means were greater than pre-test means. This shows that both teaching methods have relative effects on female students' interest in electrical installation and maintenance work than demonstration teaching method.

\subsection{For Null Hypotheses1}

\begin{tabular}{|c|c|c|c|c|c|}
\hline Source of Variation & $\begin{array}{c}\text { Sum of } \\
\text { Square }\end{array}$ & Df & $\begin{array}{c}\text { Mean } \\
\text { Square }\end{array}$ & F & Sig. \\
\hline Gender & 23.679 & 1 & 23.679 & 247.443 & .000 \\
\hline Method*Gender & .024 & 1 & 024 & 0.003 & .958 \\
\hline Error & 625.219 & 77 & 8.336 & & \\
\hline Total & 18636.000 & 80 & & & \\
\hline Corrected Total & 1112.800 & 79 & & & \\
\hline
\end{tabular}

Table 5: Summary of Analysis of Covariance of Academic Achievement Mean Scores of Psychomotor

Skills of Male Students Taught Using Demonstration And That Of Those Taught Using Project-Based Method Of Teaching

Table 5 shows the probability value associated with the calculated value of F (247.443) is 0.000 . Since this value 0.000 is less than the 0.05 level of significance, the null hypothesis is rejected. It means that there is significant difference in the academic achievement mean scores of psychomotor skill of male students taught electrical installation and maintenance work using demonstration teaching method and those taught using project-based teaching method. The null hypothesis was, therefore, rejected. However, the direction of the difference is in favour of the project-based teaching method which had a higher post-test mean achievement score as shown in Table 1.

\subsection{For Hypothesis 2}

\begin{tabular}{|c|c|c|c|c|c|}
\hline Source of Variation & $\begin{array}{c}\text { Sum of } \\
\text { Squares }\end{array}$ & Df & $\begin{array}{c}\text { Mean } \\
\text { Square }\end{array}$ & F & Sig. \\
\hline Gender & .053 & 1 & .053 & .404 & .526 \\
\hline Group* Gender & .445 & 1 & .445 & 3.380 & .068 \\
\hline Error & 17.779 & 137 & .132 & & \\
\hline Total & 1891.825 & 140 & & & \\
\hline Corrected Total & 18.636 & 139 & & & \\
\hline
\end{tabular}

Table 6: Summary of Analysis of Covariance of Interest Mean Scores of Male Students Taught Using Demonstration Teaching Method and Those Taught Using Project-Based Teaching Method

Table 6 shows the probability value associated with the calculated value of F (0.404) is 0.526 . Since this value 0.526 is greater than the 0.05 level of significance, the null hypothesis is accepted. It means that there is no significant differences in the interest mean scores of male students taught electrical installation and maintenance work using demonstration teaching method and those taught using project-based teaching method. This means that both demonstration and project-based promotes male students interest as shown in table 2.

\subsection{For Hypothesis 3}

\begin{tabular}{|c|c|c|c|c|c|}
\hline Source of Variation & $\begin{array}{c}\text { Sum of } \\
\text { Square }\end{array}$ & Df & $\begin{array}{c}\text { Mean } \\
\text { Square }\end{array}$ & F & Sig. \\
\hline Gender & 23.679 & 1 & 23.679 & 247.443 & .000 \\
\hline Method*Gender & .024 & 1 & 024 & 0.003 & .958 \\
\hline Error & 625.219 & 77 & 8.336 & & \\
\hline Total & 18636.000 & 80 & & & \\
\hline Corrected Total & 1112.800 & 79 & & & \\
\hline
\end{tabular}

Table 7:Summary of Analysis of Covariance of Pre-Test and Post-Test Academic Achievement Mean Scores of Psychomotor Skills of Female Students Taught Using Demonstration Teaching Method and Those Taught Using Project-Based Teaching Method 
Table 7 shows the probability value associated with the calculated value of $F(247.443)$ is 0.000 . Since this value 0.000 is less than the 0.05 level of significance, the null hypothesis is rejected. It means that there is significant difference in the academic achievement mean scores of psychomotor skill of female students taught electrical installation and maintenance work using demonstration teaching method and those taught using project-based teaching method. The null hypothesis was, therefore, rejected. However, the direction of the difference is in favour of the project-based teaching method which had a higher post-test mean achievement score as shown in Table 3.

\subsection{For Hypothesis 4}

\begin{tabular}{|c|c|c|c|c|c|}
\hline Source of Variation & $\begin{array}{c}\text { Sum of } \\
\text { Squares }\end{array}$ & Df & $\begin{array}{c}\text { Mean } \\
\text { Square }\end{array}$ & F & Sig. \\
\hline Gender & .053 & 1 & .053 & .404 & .526 \\
\hline Group* Gender & .445 & 1 & .445 & 3.380 & .068 \\
\hline Error & 17.779 & 137 & .132 & & \\
\hline Total & 1891.825 & 140 & & & \\
\hline Corrected Total & 18.636 & 139 & & & \\
\hline
\end{tabular}

Table 8: Summary of Analysis of Covariance of Interest Mean Scores of Female Students Taught Using

Demonstration Teaching Method And Those Taught Using Project-Based Teaching Method

Table 8, shows the probability value associated with the calculated value of F (0.404) is 0.526 . Since this value 0.526 is greater than the 0.05 level of significance, the null hypothesis is accepted. It means that there is no significant differences in the interest mean scores of female students taught electrical installation and maintenance work using demonstration teaching method and those taught using project-based teaching method. This means that both demonstration and project-based promotes female students interest as shown in table 4.

\section{Discussion of Finding}

Findings of the study show that project-based teaching method has more relative effect on male students' psychomotor skill development than demonstration teaching method. Similarly, the probability value associated with calculated F-value of 0.000 was less than the alpha level of $0.05(0.000<0.05)$ indicating that there was significant difference in the relative effectiveness of demonstration and project-based teaching methods in psychomotor skills development of male students in electrical installation and maintenance work in favour of the group taught with project-based teaching method. This finding conforms to that of Omeje (2011) who conducted an experimental study to determine the effects of project-based teaching method on the academic achievement, interest and retention of low ability students in carpentry and joinery in technical colleges and reported that male students taught using project-based teaching method performed better in psychomotor skills than those taught using conventional method. This could be as a result of workshop safety compliance as revealed by the study of Bassey, Amadike, Nsikan and Segbara (2016) who carried out a study to investigate the relationship between workshop safety compliance and students psychomotor skills acquisition and found that there was high positive significant relationship between safety compliance in the use of appropriate tools and students' psychomotor skills acquisition in electrical installation and maintenance work.

Furthermore, findings of the study revealed that demonstration and project-based teaching methods promoted the students' interest in electrical installation and maintenance work with very minimal difference in favour of the project-based teaching method. The probability value associated with calculated F-value of 0.526 was greater than the alpha level of 0.05 $(0.526>0.05$ showing that there was no significant difference in the relative effectiveness of the two teaching methods on male students' interest in electrical installation and maintenance. This finding has a bearing with Ayonmike (2014) who posited that males show interest in physical and competitive activities.

Findings of the study showed that project-based teaching method had more relative effect on female students' psychomotor skill development in electrical installation and maintenance work trade than demonstration teaching method. Similarly, the probability value associated with calculated F-value of 0.000 was less than the alpha value of $0.05(0.000<0.05)$ showing that there was significant difference in the relative effectiveness of the two teaching methods in psychomotor skill development of female students in electrical installation and maintenance work in favour of project-based method. This finding agrees with that of Okoro (2013) who conducted an experimental study on the effect of project-based teaching method on secondary school students' academic achievement, interest and retention in Home Economic reported that the method enhanced female students' achievement in the subject. The finding is also in line with the assertion of Udofia and Udofia (2013) that teaching methods that encourage group work such as project-based teaching method favors female students. This is understandable because female students prefer working in groups in physical related activities as noted by Okigbo and Okeke (2011).

Findings of the study revealed that demonstration and project-based teaching methods equally promoted female students' interest in electrical installation and maintenance work trade with insignificant difference in favour of project-based method. Similarly, the probability value associated with calculated -F-value of 0.281 is greater than the alpha level of 0.05 $(0.281>0.05)$ showing that there was no significant difference in the relative effectiveness of demonstration and project-based teaching methods on female students' interest in electrical installation and maintenance work. The finding is in consonance with the reports of Omeje (2011) and Ayonmike (2014) that activity-based teaching methods had more positive effect on female students' interest in carpentry and joinery and in brick/block-laying and concreting respectively. 


\section{Conclusion}

Based on the findings, it was concluded that the use of demonstration and project-based teaching methods by technical teachers will lead to an improvement in students' psychomotor skills development and interest in electrical installation and maintenance work trade in technical colleges.

\section{Recommendation}

Based on the findings of the study, the following recommendations were made:

- Administrators of technical colleges should ensure that number of students in a class does not exceed the ratio of 1:20 to facilitate teachers' adoption of the activity-based teaching methods used in the study for full participation of students in teaching and learning process to facilitate psychomotor skills development and interest of both male and female students.

- Technical teachers should use the activity-based methods used in the study for effective teaching and learning of technical subjects in order to develop psychomotor skills in learners. This will go a long way to help students acquire the necessary practical skills and competencies to perform effectively in employment and become self-reliant in their respective trades.

- Higher educational institutions producing technical teachers should update their curricular to incorporate the use of practical-based teaching methods like demonstration and project-based teaching methods so that the graduates can use them successfully in teaching their students.

\section{References}

i. Agbejoye S. J. \&Adegbola A. J. (2017). Gender and workshop facilities as determinant of student' performance in tertiary technical institution for sustainable economic recovery in Nigeria. Journal of Nigerian Association of Teachers of Technology (JONATT), $211-218$

ii. Ayonmike, C. S. (2014) Comparative effectiveness of three teaching methods on students' psychomotor performance in brick/block-laying and concreting in Delta State College. UnpublishedPh.DThesis. Department of Vocational Education, Faculty of Education, NnamdiAzikiwe University, Awka.

iii. Bassey E. J., Amadike O., Nsikan J. O. \&Segbara D. G. (2016).Workshop safety compliance and students' psychomotor skill acquisition in electrical installation works in technical colleges in Akwalbom State, Nigeria. African Education indices, $9(1), 18-33$.

iv. Daluba, N.E. (2013). Effect of demonstration method of teaching on students' achievement in agricultural science. International Journal of modern social science., 3,(6),http://www.sciedu.ca/wje.Retrieved 25 ${ }^{\text {th }}$ September, 2018.

v. Edu, D.O, Ayang, E.E, \&Idaka, I (2012).Evaluation of instructional methods and aptitude effects on the psychomotor performance in basic electricity among technical students in southern educational zone, Cross River State Nigeria.American International Journal of ComtemporaryReseach, 2 (2),117-123Retrieve on $4^{\text {th }}$ September 2017 from www.aijcrnet.com

vi. Eze, T.I. \&Oguyi, S.O. (2018). Effects of problem-based teaching on students academic performance in electrical installation and maintenance work in technical colleges in Edo State. International Journal of Development and Sustainability, 7(2) ,666-678. Retrieved on September 2018 from www.isdsnet.com/ijds.

vii. Ezeh, M.O. (2006). Effects of the use of scale models on academic achievement and interest of students in map work.Unpublished doctoral dissertation, Department of Vocational Teacher Education. University of Nigeria, Nsukka.

viii. Federal Government of Nigeria (2014).Nigeria industrial revolution plan (NIRP). Abuja: Author.

ix. National Board for Technical Education.(2010). Electrical/electronic technology curriculum and course specification, Kaduna.

x. Ogbuanya, T.C. \&Akinduro, I.R. (2017). Effects of floating facilitator and peer tutor instructional approach on students' psychomotor achievement in electrical installation and maintenance work in technical colleges in Ondo State Nigeria.Globa Journal. 13 (6), 23447-2371Retrievedon15 ${ }^{\text {th }}$ September2018from http://www.ripublication.com

xi. Okigbo,E.C\&Okeke S.O.S (2011).Effects of games and analogies on students' interest in mathematics.Journal of Science Teachers Association of Nigeria, 46(1), 110-111.

xii. Okoro, R.C. (2013). Effects of project-based learning on secondary school students' academic achievement, inerest and retention in home economics.UnpublisedMscthesis.Department of Arts Education.University of Nigeria, Nsukka.

xiii. Okoye, K.R.E. (2016). Education that matters; roadmap to achieving and sustaining national development. A key note address presented at the $4^{\text {th }}$ South East COEASU zonal conference held at Enugu state college of Education (Technical) Enugu, September, 1-7.

xiv. Omege,H.O. (2011) Effects of project-based learning instructional techniques on interest and retention of low ability students in woodwork. Journal of Nigerian Association of Teachers of Technology (NATT), 7(3), 20-33.

xv. Omeje, H.O. \&Onaga, P.O (2015).Teaching vocational and technical education.Quiptechs Creation Enugu.

xvi. Udofia, A.E, Ekpo, A.B, Nsa, E.O \&Akpan, E.O. (2012). Instructional variables and students educational in Nigerian technical colleges scholarly. Journal of Educational,1(2), 13-19 Retrieved on $7^{\text {th }}$ September 2018 from http://www.scholarly-journals.com/SJE. 